\title{
For a Cultural Anthropology of the last Neanderthals
}

\author{
Ludovic Slimak
}

\begin{abstract}
CNRS, UMR5608, Université Toulouse - Jean Jaurès Maison de la Recherche Bât 26 Laboratoire TRACES 5, allée Antonio Machado 31058 Toulouse Cedex.

slimak@univ-tlse2.fr
\end{abstract}

\begin{abstract}
:
The chronological and territorial expansion of neandertalian societies, their capacities of adaptation and expansion, show that their brutal extinction, which not only affects their ways of life but also their biological reality, cannot be rationally imputed to a natural process. As a result, we here propose that theories addressing these extinctions through these prisms cannot account for the adaptive ubiquity of these societies, or for the vast territories on which these groups settled. It appears more than ever essential to look for the processes in question in relation with thei cultural anthropology of the concerned societies. Neandertal extinction remains a purely speculative scientific field, but considering the remarkable adaptative abilities revealed by these populations, we assume on our own that climatic change, modification to environments, disappearance of traditionally hunted fauna or a subtle combination of all of these causes would thus be considered as extremely secondary in that extinction process. These factors, whose only limits are the imagination of researchers, who are distant spectators of this replacement, cannot account for the primary processes of this hominin disappearance.
\end{abstract}

The approach angle is considered here as a presupposition, yet research as a discipline does not require the alignment of concepts developed by researchers but rather the demonstration of their logical constructs. Should this process be above all, not to say exclusively, approached from the point of view of the history and the sociology of these past societies? How can we understand that, after 150 years of archaeology, one of the most recent and most important hominin extinction remains focused in the Natural Sciences sphere, with no fundamental construction of a Cultural Anthropology of the last Neanderthals?

More deeply, we must investigate the ethological and anthropological structures of these populations. Does a Neanderthalian ethology ever existed? The question of the identification of an ethology of biologically fossil societies cannot be evaluated on the notions of presence/absence of archaeological realities to which we subjectively confer a discriminating function (a bone tool, an ornament, a grave, -...-), but by exploring the logical identification of all the technical and cultural products of these societies. These heuristic paths are promising and still have to be scientifically explored.

Keywords: Neanderthal extinction - Cultural Anthropology -Grotte Mandrin

\section{Why we shall, finally, build a Cultural Anthropology of the last Neanderthals ?}


Neanderthalian societies colonized immense territories. They even may well be the first humanity to conquer and exploit most of the environmental diversity of the planet. The success of these implantations and their marked dynamism raise the fundamental problem of processes in relation to their rapid and synchronous eradication throughout Eurasia. Their millennial adaptation to all biotopes and climatic environments of the Eurasian supercontinent let the scientific community with no obvious explanations of their sudden disappearance. If the Neanderthal expansion is now identified from the Atlantic coast to Siberia (Krause et al. 2007), the true expansion of these populations may well have been much more extensive. In the absence of diagnostic fossils, could we identify Neanderthals on the basis of remains from their Mousterian cultures (e.g. Li et al. 2018)? Can we envision an expansion from the Atlantic to the Pacific shores? Data are lacking and the objects abandoned by Neanderthal populations reveal the existence of a profound sociodiversity which is still only very partially understood. The chronological and territorial expansion of these societies, their capacities of adaptation and expansion, show that this brutal extinction, which not only affects their ways of life but also their biological reality, cannot be rationally imputed to a natural process. As a result, we here propose that theories addressing these extinctions through these prisms cannot account for the adaptive ubiquity of these societies, or for the vast territories on which these groups settled. It appears more than ever essential to look for the processes in question. Considering the remarkable adaptative abilities revealed by these populations, we assume on our own that climatic change, modification to environments, disappearance of traditionally hunted fauna or a subtle combination of all of these causes would thus be considered as extremely secondary in that extinction process. These factors, whose only limits are the imagination of researchers, who are distant spectators of this replacement, cannot account for the primary processes of these extinctions. Neandertal extinction remains a purely speculative scientific field.

The approach angle is considered here as a presupposition, yet research as a discipline does not require the alignment of concepts developed by researchers but rather the demonstration of their logical constructs. Should this process be above all, not to say exclusively, approached from the point of view of the history and the sociology of these past societies? How can we understand that, after 150 years of archaeology, one of the most recent and most important hominin extinction remains focused in the Natural Sciences sphere, with no fundamental construction of a Cultural Anthropology of the last Neanderthals?

We can draw a direct parallel between this problem and that of traditional societies on the American continents which were not supplanted by the cold, or by a lack of protein, or by any other far-fetched cause, but, first and foremost by the arrival of dynamic and colonizing populations. All the rest is history, and sociology. And although from our distant viewpoint, the processes affecting these societies appear to have identical outcomes, the history of the Atikamekws of Quebec is not the same as that of the Nambikwaras of Mato Grosso. Approaching the question of Neanderthal extinction without focusing on the human societies at issue would be equivalent to addressing the question of the replacement of native American populations by giving a secondary role to the natives and European colons in historic processes where they are the sole actors. According to our presupposition, native American populations did not die from the cold and did not melt like ice in the sun. Nor did Neanderthal.

It is thus necessary to explore 1/ what these famous Neanderthal societies are, 2/ what the "biologically modern" societies that replaced them are from a cultural and structural perspective 
and 3/ to envision possible links between each group in each of the concerned territories. And just as the Atikamekws are not Nambikwaras, we will immediately understand that the Neanderthal/modern question is itself a non-issue. A structured approach based on the bipolarization of these anthropological realities does not in any case enable us to document the socio-diversity of these populations and the historic interactions that they developed. On the resolution scale of interest here for assessing these replacement processes, Neanderthal and Sapiens are generic concepts which do not enable us to tackle the heart of the processes that brought about the eradication of the populations implanted in Eurasian territories. At first glance, the only question that should be rationally placed at the centre of our preoccupations is thus based on the accurate identification of the social and cultural organizations of these human groups in each of the concerned territories. Here, the cultural characters are subject to an area of archaeological visibility. They are thus approached through our perception of their material expressions, which represent the technical, social, symbolic and hunting skills of these populations. Secondly, the specific interactions developed by these societies must be defined, when new modern populations arrived with different genes and cultures. The identification of still poorly defined genetic leaks (since Green et al., 2010) does not shed any light on the processes at work. We know effectively today how to objectively define whether the tiny percentage of genes of Neanderthal origin, discernible among present-day Eurasian populations, marks a genetic acquisition corresponding to phases of colonization of European territories by Homo sapiens, or whether this acquisition is considerably older. Therefore, for now, genetics cannot reply to our questions. If we conserve the example of the Americas, the presence of genes of Aboriginal origin in many Irish, Portuguese or Italian descendants does not provide information on the specific and fundamentally distinct historic processes in which populations were involved from the Canadian Arctic to the great Amazonian forest.

The main heuristic limit of these American parallels comes from the fact that the divergences between Europeans and Americans were wholly related to their cultural structures. And yet, the Valladolid controversy reminds us that, in good faith, and for several centuries, the perception of Indians as humans was far from evident (e.g. Lévi-Strauss 1952). Are the Indians really creatures created by God, like us? Without succumbing to illusions of anachronisms preventing us from understanding societies that we consider close to ours (the European populations who colonized the Americas), it has to be accepted that the reply to this question was inextricably linked to the modes of perception of the world at that time.

Could these world views still be at work in the unconscious representations delimiting our capacities for understanding what Neanderthal was? Indeed, a branch of research postulates that in behavioural terms, Neanderthal populations present no structural divergence from modern populations. This Latin branch is mainly composed of Italian, Portuguese and French researchers and is opposed to Anglo-Saxon approaches highlighting a fundamentally archaic character of these populations. It is possible to suggest that both the Latin and Anglo-Saxon approaches are respectively based on perfectly circular reasoning as the traits described as "modern" and retained by both schools of thought to distinguish or relate Neanderthal to Sapiens are in fact the same cooking list unfolding a set of traits supposed to enable them to diagnose an accomplished humanity; art, burials, ornaments (...). Whatever use is made of these "behavioural" cooking lists (these archaeological "decoders of behavioural modernity"), they amount to projecting onto Neanderthal populations the archaeological perception we have of early Homo sapiens, with no hindsight. In parallel, on the same archaeological bases, envisioning that Neanderthal populations 
were modern is like denying, with no hindsight, the possible ethological singularity of these populations. The simplification of Neanderthal to ourselves is intrinsically, and paradoxically, subject to an unconscious racist expression; we are Humans and in order to join us among Humans, the other hominids should be like our ancestors were. If we retreat from these approaches, which aim to be comparatist, but which are based on superficial similarities and dissimilarities, the problem should be rationally recentred on the ethological definition of these populations. The question is not to determine if Neanderthal was modern (and if he was only our mirror image, we would have to admit that he was a lot less interesting than previously thought), which would be like reducing Neanderthal to ourselves, but to objectivise Neanderthal; did a Neanderthal ethology exist? These lines of thought have been explored since the 1960s and raise the question of the existence of potentially progressive processes regarding the emergence of some of the fundamental characters for defining our humanity, and which could be defined as early as the Mousterian, although their emergence would not be sudden or transposable from modern societies to "pre-Sapiens" fossil societies (L.R. Binford 1962, 1963, 1968). This exploration of the cognitive and psychological implications of cultural productions implies that the function of style, as observed in the Upper Palaeolithic industries with modern men, should be thought like a set of means enabling groups and individuals to identify themselves in territories with products or sets of cultural products, and that this property of modern societies would undergo declensions and variations in other past humanities (S. Binford 1968). We would then have to understand the degrees of this alterity and their delimitation in our own conceptions as to the possibility of a continuity in intellectual capacities, at least over several hundreds of millennia (Lévi-Strauss 1968).

These lines of thought suggest, with 50 years of hindsight, that the question of the identification of an ethology of biologically fossil societies cannot be evaluated on the notions of presence/absence of archaeological realities to which we subjectively confer a discriminating function (a bone tool, an ornament, a grave, -...-), but that we must explore the logical identification of all the technical and cultural products of these societies. These proposals, based on a structural approach of human productions, were advanced at a time when structural anthropology transformed our understanding of the world by revealing the existence of unconscious structures organising human societies, and opened the path in prehistory, from the 1960s onwards, to promising approaches which have still not been explored.

Should we not consider our attempts at generic modelling to be questionable - in our unconscious distortions -based on implicit or poorly understood presuppositions? and refocus our attention directly on the internal links of the analysed systems to determine and decrypt the archaeologically fossilized technical and social structures.

\section{An introduction to the end... Overview of the last Neanderthals in Europe}

The very long time period of the Middle Paleolithic closed for most of the European territories at the turn of the $42^{\text {nd }}$ and $43^{\text {rd }}$ millennia (Higham et al. 2014). In some geographical areas, perhaps situated at the periphery of the pattern generally documented on the continent, a few rare Mousterian groups could have experienced a perpetuation exceeding their continental extinction by ten millennia. Thus, both extremities of Europe, the southern tip of the Iberian Peninsula (e.g. 
Zilhao et al. 2017) and the boreal spaces of the Polar Urals, seem to resist the critical analysis of data. This exceptional persistence of Mousterian (and Neanderthal?) groups further illuminates the eminently complex characteristic of the general pattern of the Middle Paleolithic societies' extinction (Slimak et al. 2011).

In different parts of Eurasia, this final period of the Middle Paleolithic saw the emergence of more advanced lithic industries, already engaged in the Upper Paleolithic. For Eurasia as a whole, only two archaeological sequences, one in the Crimea and the other in Mediterranean France, document the replacement of this type of lithic assemblages by classical Middle Paleolithic industries (infra), making it possible to perceive that we are facing a historical process, both complex and potentially reversible. These early expressions of the Upper Paleolithic have been individualized under various generic names: transitional industries, Initial Upper Paleolithic or intermediate industries. They are covering highly diversified technical realities of regional value, generally with a rather limited territorial extension. Northern Europe records a "super-group", the "LRJ" -still poorly understood in its geographical and chronological extension- that groups together three assemblages originally recognized separately: the Lincombian, the Ranisian and the Jerzmanovician (LRJ), characterized by laminar debitages modified by covering retouches (Flas 2011). Once considered as the transitional industry of Western Europe, the Chatelperronian only has in fact an extension limited to southwestern France. A few rare occurrences stand out from this geographical space, such as the Grotte des Fées in Châtelperron in the Allier department or Arcy-sur-Cure in northern Burgundy. The sites of Cueva Morin, El Pendo, Labeko Koba, Ekain and the Aranbaltza open-air site (Arrizabalaga, 2000; Zilhao, 2006; Rios-Garaizar et al., 2012; Ruebens et al., 2015) delimit the southern extension of this regional group along the Basque-Cantabrian coast at the Spanish border. It is probably because of this very slight Spanish overflow that these Chatelperronian assemblages were, for a time, perceived as properly WestEuropean. The extension of this group appears well delimited today and its core essentially circumscribed to a fraction of the French Atlantic space (Bachellerie, 2011; Ruebens et al., 2015). Apart from this Atlantic area that covers less than $1 \%$ of present Spain, the vast territory of the Iberian Peninsula did not experience the development, albeit pan-Eurasian, of these so-called transitional industries. The peninsula then constitutes a singular and particularly interesting case, isolating itself from the rest of continental Europe in which the traditionally Mousterian industries of the Middle Paleolithic endured until the intrusive arrival of the "true" Upper Paleolithic in the shape of various Aurignacians. At the scale of the European continent, very few geographical areas are known in which "transitional" evolving industries are not archaeologically recorded, and the late characteristic of some Iberian Mousterian expressions is still being discussed within the scientific community (e.g. Higham et al 2014 vs Zilhao et al. 2017). It can be noted that on this vast territory the conjunction between the absence of transitional industries and a persistence of the Mousterian traditions would tend to reinforce the thesis of the persistence of Neanderthal societies in these peninsular margins. In the extreme northern part of Europe, a fairly comparable process, on a general level, is documented with the Byzovaya deposit. 
Located on the Arctic Circle, it represents one of the three northernmost sites identified to date, before the great cold of the Last Glacial Maximum a little more than 20,000 years ago. The boreal assemblage of Byzovaya is characterized by the accumulation of bones from several dozens of mammoths. While the associated stone tools are undoubtedly Mousterian (Slimak et al., 2011; Slimak et al., 2012), a large corpus of forty radiometric measurements, including tools made of mammoth bones or cut-marked, makes it possible to assert that this homogeneous Mousterian assemblage is not older than thirty millennia.

This Mousterian assemblage is precisely situated within the ten to fifteen millennia after the emergence of the Upper Paleolithic on most of the European continent. This isolated case in the high latitudes presents a singular importance for understanding the replacement processes of the Middle Paleolithic societies. A few hundred kilometers to the south, still in this Uralian space, the sites of Zaozer'e and Garchi are showing very distinct technical realities in highly similar chronologies; Zaozer'e illustrates the systematic production of perfectly "Upper Paleolithic" blades and bladelets, obtained by organic percussion, and Garchi the search for thin foliate projectile points (Slimak et al., 2012). These categories of thin foliate pieces with a concave base, partly obtained by pressure shaping, have a special value, since they are found as early as the end of the Middle Paleolithic on a huge territory ranging from the subpolar zone, at Garchi, as far as the Caucasian shores of the Black Sea, at Byryuchya Balka; they can be recognized across the great Russian plain as far as western Ukraine.

This remarkable distribution makes these industries, known as Streletskian (from the Kostienki Streletskaya deposit) or Streletsko-Sungirian, the largest "transitional" group documented up to date in Europe, before which the Chatelperronian appears as a regional anecdote. This environmental and cultural complex discernible over immense geographical areas is certainly not central enough in the questioning relating to these transitional issues. Indeed, researchers usually focus on a few emblematic cultural assemblages, among which the French Chatelperronian, the Italian and Hellenic Uluzzian and the Central European Bohunician stand out almost systematically. In this trio of industries, the Chatelperronian only has a local value, the Uluzzian remains technically ill-defined and the Bohunician only offers lithic industries, without fauna, commonly without reliable stratigraphy, and it is still poorly delimited in its chronological realities. Concerning the Uluzzian and the Chatelperronian, Western "Eurocentrism" most certainly explains the value that is commonly given to them in the scientific literature. Their comparison, even if generic, on the basis of the presence of curved backed elements, as has sometimes been proposed, should be abandoned, as these industries do not technically have any common base. The place given to the Bohunician, which is found mainly in the Czech and Slovak Republics, can certainly be explained by the technical proximities attributed in relation to the Levantine assemblages, probably sub-contemporary, of the Initial Upper Paleolithic (IUP) (Tostevin, 2000; Skrdla, 2003). These true proximities, however, rely exclusively on rather 
generic aims of production (lithic points with Levallois characteristic, generally non-retouched) and not on precise technical similarities; the Bohunician is indeed characterized by bipolar debitages, which do not correspond to the productions documented in the Levantine IUP and, moreover, which gives the Bohunician points, at a morphological level, a very particular shoulder that is not found in the assemblages from the eastern Mediterranean (Slimak, 2004). On the other hand, productions that are very similar to those of the Bohunician can be recognized on the western side of the Ukraine in the Kremenician assemblages of Kulichivka (Meignen, 2006). The Bohunician, affiliated to the Kremenician, would have had then a fairly large extension affecting a notable part of Central Europe, although its distribution can in no way be compared with that of the Streletskian. We have seen the pan-European amplitude of the latter, which, even in notably more recent phases of the Upper Paleolithic, only had few equivalents in the history of the peopling of Europe.

While the geographical distribution of cultural assemblages, or of technical solutions shared by different groups, do not make it possible to assess the importance of these assemblages in the processes that have influenced the end of the Middle Paleolithic period, the existence of cultural groups covering significantly larger areas in the territories of Central and Eastern Europe can nevertheless be pointed out. In Central Europe, the technical convergence between the Bohunician and the Initial Upper Paleolithic of the Levant, even generic, since the technical systems are diverging in the detail, is indeed troubling; thus we can see in a similar chronology, from central Europe to the eastern Mediterranean, that the human groups produced points from systems showing technical origins indisputably inherited from the old Mousterian spheres. If the geometry of the cores and the dynamics of exploitation of these debitages, which begin with a strictly laminar phase, cannot be considered as Levallois, it is here the notion of predetermination of the sought-after products - points - that is showing an obvious rooting in the notions proper to the Levallois debitages. Finally, in the Bohunician as in the Initial Upper Paleolithic, these points, highly predetermined from the debitage, are essentially used untreated, very rarely including secondary modifications affecting their cutting edge. But the technical connections stop there and the direct analysis of the entire archaeological sequence of Ksar Akil (LS), the main Levantine sequence with regard to the question of the transition from the Middle Paleolithic to the Upper Paleolithic, does not allow us to propose more than a highly generic technical convergence with no obvious possibility of a precise community of knowledge.

In a more general manner, this idea of producing "points" or rather "pointed" objects in this transitional phase seems to be shared by a large part of these groups (Teyssandier et al., 2010), which usually dissociates them drastically from the local technical substrates that are preceding them locally. In the latter, the production of true points, especially Levallois, remains particularly marginal in the European Mousterian if one is somewhat rigorous with the definition and recognition of such products (Slimak, 2004; Metz, 2015). Beyond this concept of "point", which transcends the transitional industries in Eurasia, it can be noted that these elements are obtained 
from highly diversified technical solutions. One of the main issues during this transition phase is the precise function of these objects; would the emergence of these points correspond to the development of new armament solutions affecting not only the technical systems but also the logistic and social organization of the human groups in their entirety (Bon, 2005; Metz, 2015) ? Accurate functional studies are sorely lacking to answer such questionings, and the question of the actual place of the armaments, like that of the disruptions they may have induced in the technical and social organization of the human groups, cannot yet be evaluated at their exact value. It should be noted that in the Mandrin cave the precise functional analysis of several thousand pieces makes it possible to consider that the question of the transformation of armaments does indeed play a structural role in this transition mechanism. In this site, the functional analysis of the Neronian, an industry more recently identified in the Rhône Valley (Slimak, 2004, 2008), shows that these assemblages are structured around the systematic production of standardized weapons, with very small modules (Metz, 2015). These microlithic and standardized points were only able to function in the context of mechanical propulsion, bow or spear thrower. This is a particularly sophisticated technical solution that lies at the heart of the articulations between the Middle and Upper Paleolithic.

At the same time, the analysis of the entire sequence of Mandrin cave and of the assemblages that are stratigraphically bordering the Neronian show that, within the Mousterian industries of the sequence, weapons occupy only a marginal place in the technical systems. This scarcity of armaments in the Mousterian levels bordering the Neronian is harmoniously integrated with what is recorded globally in the Middle European Paleolithic in which weapons are rarely identifiable and somewhat hypothetical, if not debatable (Metz, 2015). These Mousterian weapons correspond to heavy hafted points, projected or simply driven, by hand. Apart from the fact that the diffusion of mechanical propulsions is pushed back in time with the Neronian by at least 10,000 years compared to what was previously documented in Eurasia, it is indeed the whole organization of these societies, in their technological and hunting potentialities - manner of procuring game, tenfold capacity for accessing animal proteins, organization of the global technical system... -, which makes it possible to consider that on the scale of the Eurasian West, these technologies of mechanical propulsion could have fundamentally distinguished the old societies of the Middle Paleolithic from all the groups of the Upper Paleolithic (Metz, 2015).

Two other singularities infer a special place of the Neronian in the general issue of this transition towards the Upper Paleolithic. The first one concerns its stratigraphic position since this industry does not merely close the Middle Paleolithic, as is generally the case in Europe, but is intercalated there in the local sequence of the end of the Mousterian. The second one concerns its precise technical structure, based on the systematic production of generally non-retouched points, which shows a remarkable proximity with the Levantine industries of the very beginning of the Initial Upper Paleolithic (Ksar Akil, levels XXV-XXI). The direct analysis of these industries shows that, unlike the Bohunician, the filiations that can be proposed are no longer of the order of 
the generic idea of production (producing predetermined points from technical systems that are still partially rooted in the old Levallois modes), but illustrate a strict replication of the systems; the technical systems of the Neronian in the Western Mediterranean are similar to those documented at the beginning of what is known as the Initial Upper Paleolithic in the Eastern Mediterranean.

Then, it is the interstratification of the Neronian, combined with its very short settlement duration at Mandrin cave and in this geographical space (Slimak, 2004; Vandevelde et al., 2017, 2018), which allow to rethink whole sections of this transition process. It is then possible to consider the existence of historical patterns within which the arrival of the first societies of Homo sapiens in Europe would not happen at the very time of the "Neanderthal extinction" but would precede this extinction by 7,000 to 10,000 years. This model would then be considerably more complex and potentially rich in interactions between modern and Neanderthal societies than what was hitherto foreseen. The continuation of excavations at Mandrin cave will be the key to validate or invalidate this original pattern. It should also be noted that this interstratification between a transitional industry and Middle Paleolithic assemblages, although exceptional, is not a unique configuration. The Buran Kaya III deposit in the Crimea shows the same intercalation between a transitional industry known as the "Eastern Szeletian", based on the production of partially foliate and geometric pieces and an industry that is clearly from the Middle Paleolithic (Chabai et al. 2004). Indeed, it is not so much the presence of such interstratifications that should astonish us but their exceptional characteristic. The very old dates, around the $50^{\text {th }}$ millennium, of some transitional industries - such as the Bohunician from Bohunice itself - and the very recent dates of some Mousterians, for example in Byzovaya, make it possible to consider at the sole scale of Central and Eastern Europe the coexistence of these societies in related territories for at least 20,000 years. The exceptional nature of any interstratification (two occurrences for the whole of western Eurasia) suggests particularly marked processes of territorial exclusion between societies already engaged in the Upper Paleolithic universe and the traditional indigenous groups of the Middle Paleolithic.

These questions are directly raising the issue of the biological authors of these transitional industries. It has long been suggested, essentially on the basis of the state of knowledge concerning the origins of the Chatelperronian, that they could correspond to the ultimate Neanderthal productions. It was indeed proposed that the Chatelperronian be technically rooted in regional substrates, representing the evolving form of local Mousterian industries (Bordes, 1972). The precise examination of the technical structures of the Chatelperronian (Pelegrin, 1995; Bachellerie, 2011; Roussel et al., 2016) and of these assemblages from the very end of the Middle Paleolithic period (Thiébaut, 2005; Jaubert et al., 2011; Gravina, 2016) has weakened this hypothesis, leaving the Chatelperronian technically without a direct plausible ancestor within the native Mousterian industries it replaced. Similarly, the idea of an association between Chatelperronian and Neanderthal human remains, which was thought to have been demonstrated 
on the basis of the data of Saint-Césaire and Arcy-sur-Cure, appears scientifically uncertain (BarYosef and Bordes, 2010; Bachellerie, 2011; Bordes and Teyssandier, 2010; Gravina, 2016 ; Gravina et al. 2018) and is now resting only on data isolated to groups of proteins, diagnostically fragile, associated with a single radiometric measurement on the Arcy-sur-Cure site (Welker et al., 2016).

On the other hand, the proposal of a modern human's association with the Uluzzian industries (Benazzi et al., 2011) on the basis of the teeth found at Cavallo cave must for the same reasons be considered with caution, as these teeth are isolated and their taphonomic context have also been approached with some circumspection (See Zilhao et al., 2015). It would be possible to leave this question relatively open if, by descending in time, the later data of Ksar Akil and Sungir did not show a direct and indisputable association with modern populations. This is the case of the layers XVI/XVIII of Ksar Akil ${ }^{1}$ attributed to the Early Upper Paleolithic (EUP), which represent a more recent form of the Initial Upper Paleolithic. The direct analysis of these collections by L. Slimak shows a strict technical continuity between IUP and EUP, here from layers XXV to XV. These very precise technical similarities documented in Ksar Akil do not allow doubting that we are facing the same populations, both culturally and biologically. This suggests that an association between the Levantine Initial Upper Paleolithic and modern populations appears to be the most plausible hypothesis for these groups. This situation has a direct parallel in Europe, concerning the burials of Sungir now dated to around 34,000 cal. BP (Nalawade-Chavan et al., 2014); they show an association between modern populations and the technical systems specific of the transitional phase of Eastern Europe, emphasized by the presence of concave-based foliate pieces, whose form and production modes cannot result from a hazardous similarity or from an ex nihilo reinvention. The concave-based foliate points of Sungir, unquestionably Streletskian, indicate a precise continuity of the technical knowledge of these populations.

From Eastern Europe to the Mediterranean Levant, there would be indisputable archaeological indicators between elements technically inherited from the traditions of the beginnings of the transition and from biologically modern individuals. This is an enlightening approach but that is exclusively considered from the end of a process whose extreme ethnohistorical complexity is being foreseen. It should be borne in mind that although until recently the Neanderthals were

\footnotetext{
${ }^{1}$ In most of Ewing's publications the only information provided regarding the stratigraphic location of the human bones is that they came from 11.46 m below datum; an examination of the stratigraphic section shows that this is very close to the boundary between levels XVI and XVII. However, the depth of $11.46 \mathrm{~m}$ refers to the base of the stone heap under which Egbert was found and Ewing notes that "most of the skeletal remains lie somewhat deeper than this". Newcomer remarks that $11.46 \mathrm{~m}$ below datum is deeper than the maximum depth of $11.25 \mathrm{~m}$ given for the stone artefacts recovered from level XVI and he concludes that "thus the burial would appear to be in level XVII or XVIII". As regards the archaeological materials in levels XVI-XVIII. Bergman Christopher A., Stringer Christopher B. Fifty years after: Egbert, an early Upper Palaeolithic juvenile from Ksar Akil, Lebanon. In: Paléorient, 1989 , vol. $15, n^{\circ} 2$. pp. $99-111$
} 
considered as the craftsmen of these transitional industries, no association between these assemblages and Neanderthal human remains can now be firmly demonstrated. At the same time, the increasingly precise characterization of these industries' technical systems shows, contrary to what has hitherto been considered, that these assemblages have very little chance of being able to all correspond to local and progressive evolutions of the indigenous Mousterian industries. These data would make it possible to consider from now on that the rupture between the Middle Paleolithic and the Upper Paleolithic could have been considerably more sudden than what had been envisaged, the so-called transitional industries themselves breaking with the locally documented technical knowledge in each of the concerned European territories. Such a model would induce both a biological and cultural replacement process taking full place not only with the first Upper Paleolithic stricto sensu, but also in the transitional phase. It began through western Eurasia not in the $42^{\text {nd }}$ and $43^{\text {rd }}$ millennia, but at least as early as the $50^{\text {th }}$ millennium, as shown by the chronologies of the Bohunician, the Neronian, and probably also those of the beginnings of the Initial Levantine Upper Paleolithic, if one considers for example the reference sequence of Ksar Akil - whose layer XXII would already be anterior to the $46^{\text {th }}$ millennium (Bosch et al., 2015) even though these industries are visible from layer XXV. In this general context of biological replacement and rupture of expertise and technical knowledge, the question of the origin of this process obviously arises. A commonly considered Levantine origin is far from being ascertained in view of the diversity of the cultural expressions of the European realities. On a continental scale, the assemblages of the Bohunician and even more of the Neronian are the only ones that can find Levantine parallels at various levels. The question of the continuity between the local Middle Paleolithic and the IUP, which is too commonly accepted, seems far from ascertained when we look precisely at the technical systems involved (observations by L. Slimak). Would these data suggest that in the Levant, as in Europe, these transitional industries would also be exotic and would break with the productions and technical knowledge of the last moments of the Middle Eastern Middle Paleolithic? In this geographical space, as in Europe, there is no certainty, and the continuity processes proposed there remain both fragile and debatable. In this complex historical tangle, some paradigms remain too commonly mistaken for scientific knowledge. The association between Neanderthal and Chatelperronian, the local continuity between Mousterian and "transitional" industries and the Levantine origin of the Upper Paleolithic may be considered as questionable. At the same time, the emergence of fundamental data that have gone unnoticed, including the late persistence of Middle Paleolithic forms, the precise determination in each region of the ultimate Mousterian groups, or the recognition of transitional industries like the Neronian on territories directly related to those of the Chatelperronian, allow to draw at the end of the Middle Paleolithic a cultural and anthropological landscape radically different from the perceptions accepted for several decades. These elements should make it possible, in the short term, for a global revising of this crucial phase of the history of mankind because of its articulation with the extinction of all the hominin populations then contemporary with our biological ancestors. 


\section{Rhodanian bricks to build a Cultural Anthropology of the last Neanderthals}

The vast Rhône corridor currently offers major archaeological insights into the organization of Neanderthal societies prior to their extinction in the French Mediterranean area. The archaeological documentation from this region can be seen as particularly original in view of the data commonly referenced concerning the organization of the last Neanderthal societies. It has been demonstrated, a dozen years ago, that the Rhône corridor has a historical structure strictly differentiated from that of the Atlantic area (Slimak 2004), a region that has focused, for decades, almost all the attention of the French scientific community, masking large parts of the actual complexity of the processes in which the ultimate Neanderthal societies were engaged.

In the Mediterranean area, 29 years of research on the sequence of Mandrin cave have recorded, outstandingly, 8 phases of strictly distinct human settlementsfrom the $50^{\text {th }}$ to the $42^{\text {nd }}$ millennium. The assemblage documents the organization, knowledge and the technical representations of the human societies at the precise moment when the replacement of the last Neanderthal societies by modern exotic populations took place.Mandrin cave dominates the Rhône 25 kilometers north of the Ardèche/Rhône confluence, on the left bank of the river overlooking an ancient inactive branch. This cave is a rock shelter dug at the foot of a small limestone massif that forms a promontory about twenty meters halfway up a hill, called Jas des Chèvres.

The succession of the hills of Jas des Chèvres, Montchamp and Navon blocks the valley, and forces the Rhône to pass into the narrow gorge of Donzère, south of Viviers. This gorge is formed by a line of steep cliffs whose feet are directly in the river, geographically marking the only narrow gully of the Rhône valley over its entire course, from Lyon to the Mediterranean.

The cave opens up to the north at an altitude of 225 meters and towers one hundred meter over the valley. Its vault covers a small area that was 12 meters wide by 8 meters deep and 2 meters maximum height before the archaeological excavations took place. The rocky promontory overlooking the site allows to embrace a vast landscape widely open on the alluvial plains of the Rhône and as far as the Ardèche. The cave is therefore at the crossing of several biotopes and in almost direct contact with the Maloubret flint, a source of high quality raw material that was exploited until the Neolithic.

Beyond the last millennia of the Middle Paleolithic, the complete stratigraphic sequence of Mandrin cave is divided into 9 sedimentary assemblages (top to bottom, B to J) which record, as it stands, a minimum of 11 phases of human occupations spotted by the excavation and by the statistical analysis of vertical distributions.Together, these archaeological records document climate changes and the organization of Neanderthal societies from the $100^{\text {th }}$ millennium until their extinction at the turn of the $42^{\text {nd }}$ millennium. The eight phases of human settlements recorded at the top of the sequence, in the layers B to F, have been unearthed since 1990 on about one hundred square meters. These human settlements are at the heart of our remarksabout the processes that have affected Neanderthal societies in their last millennia and until their extinction. The excavated zone covers the entire surface area under the vault of the cave and an equivalent surface area outside, beyond its porch. This configuration makes it possible to consider that,for once,the archaeological window allows to framemost of what must have corresponded to the 
heart of the domestic spaces of these societies during their visits to the cave. The sequence has yielded (excluding several million micro-fragments) some sixty thousand major lithic objects and as many faunal remains. Micro faunas, pollens and charcoals allow a complete biostratigraphical reading of these settlements. Hearths are documented in the main levels, and layer E, positioned in the $50^{\text {th }}$ millennium, has yielded the foundations of a hut showing various constructed spaces with a hearth at the entrance.In this unit, domestic activities are clearly organized according to spacesstructured byseveral circular arrangements using a thousand blocks 10 to $50 \mathrm{~cm}$ in size. Human remains have been found in the major units of the sequence.Based on about forty radiometric measurements, the chronology of this sequence (Higham et al. 2014) can be considered robust enough to support the existence of remarkably distinct traditions between the Atlantic and Mediterranean areas, synchronies affecting both the ultimate Mousterian societies and the "transition" industries in these related spaces.

These synchronies, and their implications for our conceptions of the territorial and social organizations of human societies in the last times of the Middle Paleolithic, have been hithertopartly underestimated because the records of Mandrin cave are gradually defining, for the first time, the biostratigraphical, chronological, anthropological and cultural contexts of the last moments of these Neanderthal societies at the heart of the vast Rhône Valley. These archaeological recordsare then drawing a remarkably differentiated context from its contemporary parallels of the Atlantic area.

During this 8 millennia period,four cultural phases are clearly distinguished; however,this marked diversity of technical and social expressions does not have any parallels as to the associations and paleontological representations of the fauna hunted by these human groups, which illustrates rather monotonous exploitation modes in the units of this terminal Middle Paleolithic.Each of these settlement phases has yieldedin parallel a relatively large number of lithic remains, but which is in line with the results of the paleontological analysis suggesting short-lived and probably seasonal occupations. The microchronological analysis, a very high resolution method developed at Mandrin cavefrom the analysis of soot deposits, makes it possible to document the durations separating two human settlements with a resolution of the order of the year and even of a season (Vandevelde et al., 2017, 2018).

Within this rich paleontological data, horses are still dominating, followed by deer andbison. A second group concerns the ibex, roe deer, reindeer, chamois, rhinoceros, megaloceros and proboscideans. This sequence presents a group of species predominantly cold-adapted (ibex, reindeer, chamois, bison) but also with a more temperate (deer) or drier (European ass) note.Anthropogenic actions are omnipresent on all this material whose origin must be essentially connected to hunting activities. Discernible traces on the bones indicate skinning, disarticulation and de-fleshing, but also the breakageof long bones to extract the marrow and the use of the bone residues as fuel or as tools. These objects fit fairly well into the wider diversity of bone tools recognized during the Middle Paleolithic, combining poorly modified elements, technically little invested and probably engaged in families of quite diverseactivities.In this respect, the common and generic name of retouchers or smoothers does not make it possible to define precisely either the diversity of these categories of objects nor the arrangements of committed gestures that potentially mark the exploitation of organic materials (leather, hair, tendons, bark...) so badly documented for these periods (Slimak dir. 2008). The rather common presenceon these categories of rather crude tools of percussions allowing to modify their morphology or of wear traces 
resulting from their use, are not only the mark of the remarkable capacity of innovation of the Neanderthals (that they can express in other fields of the technical processes they are implementing), but also of vast corpus of activities that are still poorly documented.

With more than a thousand typological tools and as many Levallois points, this sequence is extremely rich and complete in terms of relevance of information. It is mainly on the basis of these data that the cultural and historical structure of the last Neanderthal societies in Mediterranean France could be defined (Slimak 2004, 2008).No other assemblagefrom the French Mediterranean area, and more broadly, from northern Italy to Catalonia and up to the Paris basin to the north, offers such a wealth and continuity of archaeological recordsto address these issues.

\subsection{Cultural replacement and taking possession of territories}

The upper part of the sequence documents all the cultural reorientations currently recognized in this geographical area over the entire chronological period from the $52^{\text {nd }}$ to the $42^{\text {nd }}$ millennium. These settlements can be subdivided into four stages, from bottom to top:

- Phase I: Typically Mousterian assemblages attached to the Rhône Quina, layer F (Slimak 1998, 1999);

- Phase II: Evolving group, "transition" industry, layer E (Neronian);

- Phase III: Late groups of Mousterian tradition (two cultural phases are clearly differentiated; layer D, Post-Neronian I, layers B2, B3, C1 and C2, Post-Neronian II);

- Phase IV: Group of the very first Upper Paleolithic, layer B1 (Protoaurignacian, level 1).

This chronocultural succession is interesting from different points of view. The Neronian industries, which were foreseen 50 years ago by Jean Combier (Combier 1967) and then individualized under the name of "evolving Mousterian" (Combier 1967, 1990), were mainly recognized from old excavations with a low archeostratigraphical relevance. When these industries had been recognized, their stratigraphic position closed the Mousterian sequences, as for the Chatelperronian, for example. The stratigraphic position of the Neronian at Mandrin cave is of particular interest since these industries, whose technical peculiarities find very precise echoes in the upper Paleolithic sphere, are here replaced by classically Mousterian assemblages.For all of Eurasia, Mandrin cave is one of the only two archaeological sequences showing a stratigraphic intercalation between a "transition" group and late assemblages of Mousterian tradition (see above). This singular configuration is here to be compared with the chronology of the Neronian at Mandrin at the turn of the $50^{\text {th }}$ millennium, that is to say in a phase particularly remote in time when compared with that of "transition" industries in the neighboring territories of Burgundy, south-western France and northern Italy, in which Chatelperronian and Uluzzian chronologies hardly exceed the $44^{\text {th }} / 45^{\text {th }}$ millennium (Higham et al., 2014). The Neronian then falls into an unquestionably anterior stage, corresponding perhaps to one of the most initially recognized phases of this vast Eurasian process. It is precisely in this same chronology that we recognize industries that share a set of very precise technical characteristicson some sites in Central Europe and Eastern Mediterranean countries. 
At the end of the sequence, the chronological position of the first Protoaurignacian with regard to the last local societies of Mousterian tradition is particularly illuminating. This Protoaurignacian, positioned towards the $42^{\text {nd }}$ millennium, settles in the cave, without real rupture in time regardingthe ultimate Neanderthal societies.This chronology of the Protoaurignacian at Mandrin cave is among the oldestcurrently recorded in Europe, which may well be contemporary with some Chatelperronians such as the one found in northern Burgundy for example (Higham et al. 2014; Hublin et al., 2012).

The development of very high resolution microchronological analyzes based on the reading of the progressive deposits of soot on the walls of Mandrin cave in the various phases of human settlements show that the time span separating the final Neanderthal settlement from the first Protoaurignacian one represents, at most, a few years, if not a few seasons (Vandevelde et al. 2017, 2018).This demonstrates a direct physical encounter between Neanderthal populations and Homo sapiens on this territory: this encounter, often suggested, but on the basis of radiometric corpus, whose still uncertain resolution, at best for a few centuries or millennia for this period, has never been able to fix scientifically the concrete reality of contacts between these populations, at the scale of a site, or even of a given territory.

Such temporal resolution makes it possible, in this unique configuration, to approach time scales much lower than that of a human life and to propose here, parsimoniously, a process of replacement of societies, in the strict meaning of the term.Such an approach, based on very concrete elements of demonstration, had never been firmly supported in Eurasia, neither on the basis of stratigraphic recordings nor on the basis of too vague a chronological record. Thus, there is every reason to believe, and to lay down on a unique empirical basis, that we are registering, in Mandrin cave, the taking of possession of a Neanderthal territory by biologically modern groups.

This demonstration opens up on interpretative horizons where it can be foreseen that interactions between societies play a central role in this replacement process. If such temporal precisions, and the interpretive windows that they allow to raise, are to this day unique, this diagram reflects back to Mandrin cave a feeling of déjà vu. Indeed, microchronological analysis makes it possible to document, eight millennia before the arrival of the Protoaurignacian, a strictly comparable pattern, this time concerning the interaction between some Mousterian groups at the turn of the $50^{\text {th }}$ millennium and the Neronian, the first settlements of this group being recorded a few years, if not a few seasons, after the last Mousterian visit of layer F (Vandevelde et al., 2017, 2018).

These groups of the Neronian at Mandrin stand out due to a particularly original industry in the European context. On about 50 square meters, over 1,300 points, technically highly invested and illustrating various degrees of metric standardization, are recorded. These points are fairly light, with a maximum length of 4 to $5 \mathrm{~cm}$ and a thicknessbetween 4 and $5 \mathrm{~mm}$. One third of the points of this vast corpus is strictly microlithic, with a maximum length of less than $30 \mathrm{~mm}$, and thicknesses of 2 to $3 \mathrm{~mm}$. Within this corpus, we recognize a group of points whose maximum length is of the order of one centimeter (nanopoints, between 8 and $15 \mathrm{~mm}$ ). These systematic productions are not without a certain number of questions, since the small surface of layer E, which has been slowly excavated over the last fifteen years, has yielded more Levallois points than the cumulated assemblages of all the Middle European Paleolithic sites. More remarkably, these points, much lighter than the assemblage of points of the Middle Paleolithic of Eurasia (Metz, 2015), diverge from the classical technical systems documented during this period.These 
productions appear here as laminar and lamellar debitagesinitiated from blades and crested bladelets. Laminar, lamellar products and points represent more than $75 \%$ of the lithic industry of this archaeological layer, whereas these productions hardly reach between 4 and $6 \%$ in all the other 11 archaeological units of the sequence, proportions that are more common in the classical recordings of the Middle European Paleolithic.One of the questions raised when unearthing such objects concerns the activities in which they were used. The complete functional analysis of this corpus shows that the main technical categories of objects respond in a remarkable way to neatly distinct families of activities.Blades and bladelets have been used in domestic activities (skin removal, leather working, meat cutting...), while the points depend to a large extent on the sphere of armaments, the function as a weapon being even exclusive for the lighter, micro and nanopoints (Metz, 2015). This raises the question of the precise operating mode of these light weapons. The very numerous breakages on these elements indicate they were fitted at the end, and not laterally, making it possible to deduce a maximum infra-centimeter diameter concerning their shafts, a basic rule of efficient penetration of weapons being the existence of a binding relationship between the size of a shaft and the width of the point arming it at the end (Metz, 2015).

These data allow us to shed light on the remarkable technical structure of these Neronian industries: the profusion of points, as well as their microlithic, technically overinvested and metrically normed features, is related to the development of composite weapons, mechanically propelled, by bow or spear thrower, the nanopoints being, for their part, strictly limited to the sphere of archery (Metz, 2015).The techniques used in the lithic system, their systematization, their standardization are echoing considerably more complex technological realities, and are radicallyextracting these Neronian productions from the Middle Paleolithic sphere, such as it is documented in the other units of this vast sequence, or in the other archaeological records recognized in Europe.

Microchronological analyzes suggest that these populations, for whom the overall balance of their techniques seems to be largely limited by these weapon technologies, arrived in a territory occupied by classically Mousterian populations, whose technologies were structured around the production of massive flakes. The ultimate settlement of these very classic Middle Paleolithicgroups is only separated in time by a few years, if not a few seasons. There is then no possibility of technical or cultural continuity between these groups, however strictly contemporary, the durations of time separating them (or linking them) in this same cave being highly inferior to a human life.On the basis of technical, technological and temporal indications, the most plausible interpretation is certainly that these archaeological records document a replacement of the population in the precise territory of this cave, a pattern that is thus encountered at both ends of this sequence.

The records of Mandrin cave show the existence of Post-Neronian Mousterian traditions until the arrival of the Protoaurignacian, probably brought by modern human populations. These PostNeronian industries break with the old systems of the Neronian, as obtaining blades and pointsbecomes strictly anecdotal in this second time. These groups then appearin rupture with the technical traditions of the Neronian.This phase can be divided into two stages. The first period Post-Neronian I- is known by a unique occupation in layer D in Mandrin cave. These industries are microlithic, on flakes, and are organized through short sequences of flake debitage aimed at 
producing pseudo-Levallois points in series. These industries are characterized by the development of small pieces with truncated back, which constitute the main toolkit.

The second period -Post-Neronian II- has been recognized on four archaeological levels. These settlements are technically similar to each other and are once again in rupture with the Neronian on the one hand and the Post-Neronian I on the other. The technical systems are oriented towards obtaining large flakes for the production of massive tools with relatively classic Mousterian characteristics.The last settlements of the Post-Neronian II continue until the arrival of the Protoaurignacian, which, as we have seen, illustrates, with the Neronian, the only two moments of this sequence in which technically highly differentiated human groups share the same spacetime continuum.

Such archaeological data and readings, which are strictly empirical and based on the most precise knowledge of a rich archaeological documentation, open up vast interpretive potentialities in terms of social and historical readings. These interpretative horizons are expressed in fields radically different from the rather repetitive, if not monolithic, patterns commonly used to address the question of the last Neanderthal societies, and which occasionally give the impression that an area situatedbetween Burgundy and the Pyrenees could allow an European reading, if not an universal one, about the largest extinction of humanity recorded in Eurasia.

Here we can identify some structural characteristics and propose different interpretive tracks. At both ends of the Mandrin cave sequence, 8 millennia apart, Neronian and Protoaurignacian share a set of very precise technical features that make it possible to propose the existence of transmission, or rather here of continuities, between one and the other, the Neronian possessing all the precise technical features that one might expect from an ancestor of the Protoaurignacian.The pointed bladelets of this Protoaurignacian are obtained from the same processes than the slender micropoints typical of the Protoaurignacian. The production schemes, which are among the most technically invested, are strictly the same between this Protoaurignacian and the Neronian. The Protoaurignacian is here a hyper-lamellar, pointed universe that responds directly to the hyper-pointed, highly-slender microlithic sphere, with the same lamellar characteristic of the Neronian. Here we must exclude the question of morphological convergences: the technical similarities expressed between these two industries correspond to real communities of knowledge and production targets. The swing from a Neronian type to a Protoaurignacian type industry certainly corresponds, exclusively, to the use of mineral hammers (hard and soft stones), showing nonetheless the occasional use of organic percussion with antler or wood. The whole system corresponds also to the same sphere of expertise, in its knowledge and know-how. These similarities should be strictly interpreted as a reflection of the structural community of these societies.

If one cross-references these structural common points with the locally intrusive characteristic of these two industries, it is reasonable to assume that Mandrin Cave records the visit of exotic human groups in the vast natural circulation space of the Rhône corridor. In these two cases, these groups would clearly settle on territories still occupied by Neanderthal populations.

These intrusions, discontinuous in time but illustrating processes of continuity documented at Mandrin by both ends of the final Middle Paleolithic sequence, suggest that the transition from a Neronian industry to a Protoaurignacian industry is also an exotic process for this geographical 
space. The Mediterranean area is here immediately pointed out by the omnipresence of point productions in the eastern Mediterranean, even though these productions are extremely rare and technically rather different in the Middle Paleolithic of continental Europe (Slimak 2004, Metz 2015).

In the Mediterranean Levant, the sequence of Ksar Akil on the slopes of Mount Lebanon represents one of the best documentation of Eurasia as to the emergence of the Upper Paleolithic. The direct analysis of industries contemporary of the Neronian, called Initial Upper Paleolithic in this area, shows in the early stages of this process (layers XXV to XXI) a strict replication of the production systems and targets documented at Mandrin cave. Neronian of the Levant, or Initial Upper Paleolithic of the Rhône region, it does appear that the Mediterranean area could have represented, as early as the $50^{\text {th }}$ millennium, a space uniting human groups sharing very precise technical knowledge. The expansion processes of these populations towards Europe would have begun not only in chronologies that are considerably higher than those considered so far, but would have been based on several phases of expansions and contacts, of which only the most recent would have resulted in a true colonization of the European territories.

These data, which do not fit into any of the classical patterns of the end of the Middle Paleolithic in Europe, are certainly only touching upon the complexity of the continent's overall colonization pattern and the interactions developed by culturally and biologically distinct populations, which succeed or replace each other at different points in their history on these same areas.

At this stage, research is still limited both by the quality of available archaeological data and by the patterns structuring our views on processes whose complexity we must accept. It is necessary to analyze and deconstruct our conceptions that are both too clean and too stylized to attempt approaching complex patterns that can account for the historical processes affecting these populations.

Acknowledgements : This paper was initially written for 3 sections of a local catalog linked to «The third Man » exhibit (2017) from the National Museum of Prehistory in Les Eyzies, France. As so these ideas and concepts here exposed were essentially available to a local scale. It has been updated and specially rearticulated for this issue. Translation from french was done by Brad Gravina.

\section{References.}

Arrizabalaga A. et Altuna J. (sous la dir. de), «Labeko Koba (Pais Vasco). Hienas y Humanos en los albores del Paleolitico superior», Munibe, 2000, 52, Sociedad de Ciencias Naturales Aranzadi, San Sebastian.

Bachellerie F., «Quelle unité pour le Châtelperronien? Apport de l'analyse taphonomique et 
techno économique des industries lithiques de trois gisements aquitains de plein air: le Basté (Pyrénées-Atlantiques), Bidart (Pyrénées-Atlantiques) et Canaule II (Dordogne) », thèse de doctorat, université Bordeaux 1, 2011.

Bar-Yosef O. and Bordes J.-G., "Who were the makers of the Châtelperronian culture? », Journal of Human Evolution, 2010, 59, p. 586-593.

Benazzi S., Douka K., Fornai C., Bauer C.C., Kullmer O. et Svoboda J.« Early dispersal of modern humans in Europe and implications for Neanderthal behaviour», Nature,2010, 479, p. 525-529.

Bergman Christopher A., Stringer Christopher B. Fifty years after: Egbert, an early Upper Palaeolithic juvenile from Ksar Akil, Lebanon. In: Paléorient, 1989, vol. 15, n² . pp. 99-111.

Binford, L. R. 1962, Archaeology as Anthropology. American Antiquity. 28 (2): 217-225

Binford L.R. 1963, "Red Ocher" Caches from the Michigan Area: A Possible Case of Cultural Drift.Southwestern Journal of Anthropology 19: 89-108.

Binford L.R. 1968, Methodological Considerations of the Archaeological use of Ethnographic Data pp 268-273. in: Man the Hunter. Ed. Richard B. Lee ,Irven De Vore, Aldine Publishing Company, Chicago, $415 \mathrm{p}$.

Binford Sally R. 1968, Ethnographic Data and Understanding the Pleistocene pp 274-275, in: Man the Hunter. Ed. Richard B. Lee, Irven De Vore, Aldine Publishing Company, Chicago, 415p.

Bon F., «Little big tool : enquête autour du succès de la lamelle », in F. Le Brun-Ricalens (sous la dir. de), Productions lamellaires attribuées à l'Aurignacien, chaînes opératoires et perspectives technoculturelles, Luxembourg, MNHA, 2005, p. 479-484.

Bordes J.-G., «Du Paléolithique moyen au Paléolithique supérieur, continuité ou discontinuité ? »,Origine de l'homme moderne, Paris, Unesco, 1972, p. 211-218.

Bordes J.-G.et Teyssandier N., « The Upper Paleolithic nature of the Châtelperronian in SouthWestern France : archeostratigraphic and lithic evidence »,Quaternary International,2011, 246, p. 383-388.

Bosch M., Mannino M., Prendergast A.L., O’Connell T., Demarchi B., Taylor S., Niven L., van der Plicht J. et Hublin J.-J., « New chronology for Ksâr 'Akil (Lebanon) supports Levantine route of modern human dispersal into Europe », PNAS, 2015, 112, 25, p. 7683-7688.

Chabai VP, Marks A, Monigal K. 2004, Crimea in the context of the Eastern European Middle Paleolithic and Early Upper Paleolithic. In: Chabai VP, Monigal K, Marks AE, eds. The Middle Paleolithic and Early Upper Paleolithic of Eastern Crimea. Liège: ERAUL 104. pp 419-460.

Flas D., «The Middle to Upper Paleolithic transition in Northern Europe: the LincombianRanisian-Jerzmanowician and the issue of acculturation of the last Neanderthals », World Archaeology, 2011, 43, 4, p. 605-627. 
Gravina B., «La fin du Paléolithique moyen en Poitou-Charentes et Périgord: considérations à partir de l'étude taphonomique et technoéconomique des sites du Moustier (niveaux $G$ à K) et La Roche-à- Pierrot, Saint Césaire (niveau EJOP supérieur) », thèse de doctorat, université Bordeaux 1, 2016.

Gravina B, Bachellerie F, Caux S, Discamps E, Faivre JP, Galland A, Michel A, Teyssandier N, Bordes JG., 2018, No Reliable Evidence for a Neanderthal-Châtelperronian Association at La Roche-à-Pierrot, Saint-Césaire, Nature Sci Rep. 2018 Oct 11;8(1):15134. doi: 10.1038/s41598018-33084-9.

Green, Richard E., Krause, Johannes, Briggs, Adrian W., Maricic, Tomislav, Stenzel, Udo, Kircher, Martin, Patterson, Nick, Li, Heng, Zhai, Weiwei, Fritz, Markus Hsi-Yang, Hansen, Nancy F., Durand, Eric Y., Malaspinas, Anna-Sapfo, Jensen, Jeffrey D., Marques-Bonet, Tomas, Alkan, Can, Prüfer, Kay, Meyer, Matthias, Burbano, Hernán A., Good, Jeffrey M., Schultz, Rigo, Aximu-Petri, Ayinuer, Butthof, Anne, Höber, Barbara, Höffner, Barbara, Siegemund, Madlen, Weihmann, Antje, Nusbaum, Chad, Lander, Eric S., Russ, Carsten, Novod, Nathaniel, Affourtit, Jason, Egholm, Michael, Verna, Christine, Rudan, Pavao, Brajkovic, Dejana, Kucan, Željko, Gušic, Ivan, Doronichev, Vladimir B., Golovanova, Liubov V., Lalueza-Fox, Carles, de la Rasilla, Marco, Fortea, Javier, Rosas, Antonio, Schmitz, Ralf W., Johnson, Philip L.F., Eichler, Evan E., Falush, Daniel, Birney, Ewan, Mullikin, James C., Slatkin, Montgomery, Nielsen, Rasmus, Kelso, Janet, Lachmann, Michael, Reich, David, Pääbo, Svante 2010, A Draft Sequence of the Neandertal Genome. Science 328, 710-722.

Higham T., Douka K., Wood R., Bronk Ramsey C., Brock F., Basell L., Camps M., Arrizabalaga A., Baena J., Barroso-Ruíz C., Bergman C., Boitard C., Boscato P., Caparrós M., Conard N.J., Draily C., Froment A., Galván B., Gambassini P., Garcia-Moreno A., Grimaldi S., Haesaerts P., Holt B., Iriarte-Chiapusso M.J., Jelinek A., Jordá Pardo J.F., Maíllo-Fernández J.M., Marom A., Maroto J., Menéndez M., Metz L., Morin E., Moroni A., Negrino F., Panagopoulou E., Peresani M., Pirson S., de la Rasilla M., Riel-Salvatore J., Ronchitelli A., Santamaria D., Semal P., Slimak L., Soler J., Soler N., Villaluenga A., Pinhasi R., Jacobi R. 2014, The timing and spatiotemporal patterning of Neanderthal disappearance. Nature 512:306-309.

Hublin, J.-J., Talamo, S., Julien, M., David, F., Connet, N., Bodu, P., Vandermeersch, B. and M.P. Richards. (2012). Radiocarbon dates from the Grotte du Renne and Saint-Césaire support a Neandertal origin for the Châtelperronian. Proceedings of the National Academy of Sciences of the United States of America. 109(46):18743-18748.

Jaubert J., Bordes J.-G., Discamps E. et Gravina B., «A new look at the end of the Middle Palaeolithicsequence in Southwestern France», in Derevianko A.P., Shunkov S. (eds.), Characteristic features of the Middle to Upper Paleolithic transition in Eurasia, Asian Palaeolithic Association, 2011,p. 102-111.

Krause J., Orlando L. Serre D., Viola B., Prüfer K., Richards M., Hublin JJ, Hänni C., Derevianko A., Pääbo S. (2007). Neanderthals in central Asia and Siberia. Nature. 449 (7164): 902-4. doi:10.1038/nature06193. 
Lévi-Strauss C. [1952] 1973. Race et Histoire. In Anthropologie structurale deux, 77-422. Paris: Plon.

Lévi-Strauss C.1968, The Concept of Primitiveness, pp 349-352, in: Man the Hunter. Ed. Richard B. Lee ,Irven De Vore, Aldine Publishing Company, Chicago, 415p.

Li, F., Kuhn, S. L., Chen, F., Wang, Y., Southon, J., Peng, F., Gao, X., 2018, The easternmost Middle Paleolithic (Mousterian) from Jinsitai Cave, North China. Journal of Human Evolution, 114, 76-84. DOI: 10.1016/j.jhevol.2017.10.004

Meignen L., «From the late Middle Paleolithic to the early Upper Paleolithic, between the Adriatic and the Caspian Sea: continuity or discontinuity? An introduction », Anthropologie, 2006, 34, 1, p. 1-7.

Metz L. 2015. Néandertal en armes? Des armes, et de l'arc, au tournant du 50ème millénaire en France Méditerranéenne", mémoire de Doctorat de l'Université d'Aix-Marseille, 410 p.

Nalawade-Chavan S., Mc Cullagh J. et Hedges R., «New Hydroxyproline Radiocarbon Dates from Sungir, Russia, Confirm Early Mid Upper Palaeolithic Burials in Eurasia », PLoS ONE, 2014, 9 (1).

Slimak, L. 2004. Les dernières expressions du Moustérien entre Loire et Rhône. Thèse de doctorat, université de Provence, 865 p.

Pelegrin, J., Technologie lithique : le Châtelperronien de Roc-de-Combe (Lot) et de La Côte (Dordogne), Paris, CNRS Editions, 1995.

Rios-Garaizar J., Libano Silvente I. et Garate Maidagan D., «El yacimiento chatelperroniense al aire libre de Aranbaltza (Barrika, Euskadi) », Munibe, 2012, 63, p. 81-92.

Roussel M., Soressi M. etHublin J.-J.,«The Châtelperronian conundrum: Blade and bladelet lithic technologies fromQuinçay, France », Journal of Human Evolution, 2016, 95, p. 13-32.

Ruebens K., McPherron S. and Hublin J.-J., «On the local Mousterian origin of the Châtelperronian: integration typo-technological, chronostratigraphic and contextual data», Journal of Human Evolution, 2015, 86, p. 55-91.

Skrdla P., «Comparison of Boker Tachtit and Stranska Skala MP/UP transitional industries », Journal of the Israel Prehistoric Society, 2003, 33, p. 37-73.

Slimak L., «Les dernières expressions du Moustérien entre Loire et Rhône », thèse de doctorat, université de Provence, 2004.

Slimak L., 2008. The Neronian and the historical structure of cultural shifts from Middle to Upper Palaeolithic in Mediterranean France. Journal of Archaeological Science, 35, 8 (2008): 2204-2214.

Slimak, L. (dir.) 2008. Artisanats et territoires des chasseurs moustériens de Champ Grand. Aixen-Provence: MMSH, 2008, 432 p. (Artisanats , Territoires; 1).

Slimak L, L. Svendsen, J.I., Mangerud J., Plisson H., Heggen H.P., Brugère A. Pavlov P.Y., «Late Mousterian persistence near the Arctic circle», Science, 2011, 332, p. 841-845. 
Slimak L., Svendsen J.I., Mangerud J., Plisson H., Heggen H.P., Brugère A., Pavlov P.Y., 2012, Response to "Comment on Late Mousterian Persistence near the Arctic Circle", Science, 335 (6065), 167.

Slon V., Fabrizio Mafessoni, Benjamin Vernot, Cesare de Filippo, Steffi Grote, Bence Viola, Mateja Hajdinjak, Stéphane Peyrégne, Sarah Nagel, Samantha Brown, Katerina Douka, Tom Higham, Maxim B. Kozlikin, Michael V. Shunkov, Anatoly P. Derevianko, Janet Kelso, Matthias Meyer, Kay Prüfer, Svante Pääbo, 2018, The genome of the offspring of a Neanderthal mother and denisovan father. Nature, 561, 113-116.

Teyssandier N., Bon F. et Bordes J.-G., «Within projectile range. Some thoughts on the appearance of the Aurignacian in Europe », Journal of Anthropological Research, 2010, 66, p. 209-229.

Thiébaut C., «Le Moustérien à denticulés : Variabilité ou diversité techno-économique », thèse de doctorat, université de Provence, 2005.

Tostevin G., «The Middle to Upper Paleolithic transition from the Levant to Central Europe : insitudevelopment or diffusion? », in J. Orschiedt and C.-G Weniger (eds.), Neanderthals and Modern Humans - Discussing the Transition: Central and Eastern Europe from 50000 30000 BP, Mettman, Neanderthal Museum, 2000, p. 92-112.

Vandevelde S., Brochier J. É., Petit C., Slimak L. 2017, When Sooted Concretions turn into Micro-chronological Archaeology. Establishment of occupations chronicles in Grotte Mandrin: rethinking the Middle to Upper Palaeolithic transition, J Hum Evol. 2017 Nov; 112:70-78. doi: 10.1016/j.jhevol.2017.07.016

Ségolène Vandevelde, Jacques Brochier, Bruno Desachy, Christophe Petit, Ludovic Slimak. 2018, Sooted concretions: A new micro-chronological tool for high temporal resolution archaeology. Quaternary International, Multidisciplinary approaches in the definition of highresolution events to interpret past human behaviour: a new challenge in archaeology, 474 (B), pp.103-118.

Welker F. et al., «Palaeoproteomic evidence identifies archaic hominins associated with the Châtelperronian at the Grotte du Renne », Proceedings of the National Academy of Sciences, 2016, voirDOI: 10.1073/pnas.1605834113.

Zilhão J., « Neandertals and Moderns mixes, and it matters », Evolutionary Anthropology, 2006, 15 , p. 183-195.

Zilhão J., Banks WE., d'Errico F. et Gioia P.,«Analysis of Site Formation and Assemblage Integrity Does Not Support Attribution of the Uluzzian to Modern Humans at Grotta del Cavallo », PLoS ONE, 2015, 10, 7.

Zilhão, J., Anesin, D., Aubry, T., Badal, E., Cabanes, D., Kehl, M., Klasen, N., Lucena, A., Martín-Lerma, I., Martínez, S., Matias, H., Susini, D., Steier, P., Wild, E.M., Angelucci, D.E., Villaverde, V., \& Zapata, J. (2017). Precise dating of the Middle-to-Upper Paleolithic transition in Murcia (Spain) supports late Neandertal persistence in Iberia. Heliyon.

DOI:10.1016/j.heliyon.2017.e00435 